\author{
Borysova T. S., \\ Candidate of Philological Sciences, \\ Associate Professor of Translation and Applied Linguistics Department
}

Kherson State University

\title{
ALLUSIVE TITLES IN STEPHEN KING'S LITERARY WORKS
}

Summary. The article deals with the stylistic potential of allusive paratextual elements in fiction works by Stephen King. It is known, that most of literary texts have a certain structure and specific communicative-pragmatic content, so in our paper we study not the text itself in its pure form, but the textual periphery which has specific meaning and influences the reader in further understanding of the story. In the thesis we have made an attempt to identify the communicative potential of paratextual elements and the ways of their language implementation, as well as to establish their functional significance on the material of S. King's stories, novels and essays. It was determined that the allusive title is a basic paratextual unit, which carries factual, conceptual and subtextual information in the literary works under analysis, as well as introduces a significant layer of cultural data into the artistic space. In order to set the reader to a certain course of events in a text S. King often uses intertextual titles, thus linking a new story with so called cultural realities. This connection is established through the submission of straightforward and transformative quotes and the involvement of well-known literary characters or other famous figures - allusions, which are very effective in strong positions. Being closely related to the subtext of a story, the allusive title promotes a coherent reading of a literary work since headings bear an exact semantic projection of the content of the corresponding text and act as an element of the "authorreader" dialogue. Paratext was found to be an invariable element of S. King's works, comprising the title, epigraphs, short prefaces and dedications, and playing an important role in artistic and semantic comprehension of the fiction. Paratext is closely associated with the further text and serves as a clearly deliberate projection of its content and a reader's guide.

Key words: paratext, paratextual element, title, allusion, projection of content.

Introduction. Our work is devoted to the consideration of the relationship between paratextual elements (an allusive title in particular) and the text of the literary works by Stephen King. We have made an attempt to review how the paratext, especially the pretext, interprets the following story and prepares the reader for its perception. The importance of the information contained in the paratext is determined by its ability to disclose the overall meaningful plan of the work. At the same time, the general background knowledge allows the author intentionally influence the reader through the purposeful selection of language units: the audience is expected to solve the puzzle of inklings contained in the allusive paratextual elements in order to perceive the whole story. The relevance of the research is substantiated by the specific role that paratext, the concept of which has appeared relatively recently in literary criticism and textology, plays a very important role in the interpretation of the author's intention. The goal is to identify the communicative potential of an allusive paratextual element and the ways of its language implementation, as well as to establish its functional significance on the material of S. King's stories, novels and essays.

Recent research and publications. In modern literary studies the interest in elements that do not fully belong to the text of a literary work but, nevertheless, constitute a whole with it, arose after the investigation of a famous French researcher Gerard Genette (1982, 1991, 1997). By paratext he understands some elements of a work of art that not only partially belong to the text itself, but, at the same time, constitute a single whole with it. In his opinion, paratext actually allows a text to become a book [6]. His ideas were later continued by C. Ashley (2001), P. Burke (2007), S. Brown (2007) and others. The linguist subdivides all paratextual elements into two broad categories: peritext and epitext. The title and subtitle, chapter headings, preface, notes, etc. belong to the peritext. The epitext is more correlated with interviews with the author, advertisements, critical reviews, etc. [8]. Paratextual elements take a strong position in the structure, since they are separated from the main text and communicatively completed. In the terminology of N. Kuzmina, such elements are extremely powerful signs, in which the presence of the author is always noticeable. In her opinion, the most important function of paratextual elements is informative, as they introduce some information about the text following them: set the theme, outline the leitmotifs of individual parts, reveal the concept, update the semantic dominant of the text, or enter some subtext information, while indicating the author's attitude to it. Paratext is a mask behind which the author hides, indirectly determining his/ her attitude to the events depicted. So, paratextual elements, "on the one hand, reveal the author's intention, on the other hand, form the reader's presupposition, create pragmatic conditions for understanding the text as a metatext" [10, p. 151].

Findings and discussions. The interpretation of the compositional structure of an artistic text traditionally begins with its name. The title of the work forms an image of the text, and the headings of the sections, being a textual supplement, are intended to help the reader to identify the meanings that are within its intentional structure. The reader retrospectively comprehends the title in relation to the whole text, as the title in full, or in a modified form participates in the semantic organization of the text. The title is interpreted as a relatively independent functional, structural, and semantic unit that can exist separately from the main body of the text and, at the same time, interpret the theme and idea of the work. L. Sakharnyy considers the name of the literary work as a special category of texts - primitive ones, which are a kind of convolution of an artistic text, which subsequently reveals all the inner potential of the name [9, p. 221]. So, our task is to see their functional workload, which will bring us closer to an adequate interpretation of the plot. 
Title words can implicitly or explicitly characterize the subject or the object that are described in the literary work. Having analyzed the structural-semantic peculiarities of S. King's headings, we have distinguished a number of options. A title may contain: a) the name of the character (Christine, Dolores Claiborne); b) the attribute, the object or some sign that should make the character closer to the reader, tell about his/her, or its age, status, etc. In this case, self-centeredness involves the subjective assessment of the main characters by the writer (Blind Willie, Gwendy's Button Box, Dolan's Cadillac); c) the name and some motive of the life or events and actions of the character. Such titles usually imply the dynamics of the story (Gerald's Game, Harvey's Dream, L.T's Theory of Pet); d) the genre type (The Chronicles of Harris Burdick, The Ballad of the Flexible Bullet, The Tale of Gray Dick); e) the protagonist's social or professional status (The Library Policeman, Big Driver, Doctor Sleep, The Lawnmower Man, The Secretary of Dreams, The Turbulence Expert); f) the place of action that not only models the space of the artistic world, but also introduces the main symbol of the work (Castle Rock, Crouch End). In addition to direct names of location, S. King often uses indirect, descriptive titles, bringing some mystery to the perception of the work (The Way Station, Under the Dome, A Very Tight Place, In the Tall Grass). Titles often reflect the author's desire for intrigue (Drunken Fireworks, I Was a Teenage Grave Robber, Riding the Bullet). For this very purpose abbreviations, capitalization, additional "non-letter" symbols may be included in the title of the works (1408, The 43 $3^{\text {rd }}$ Dream, From a Buick 8, N, Mile 8, Shadows 4, Squad D).

In order to set the reader to a certain course of events in a text S. King often uses intertextuality in the title, linking a new story with so called cultural realities. This connection is established through the submission of straightforward and transformative quotes and the involvement of well-known literary characters or other famous figures - that is - allusions, which are very effective in strong positions. The pragmatic content of allusive headings is revealed retrospectively after reading the literary works. At the same time, the general background knowledge of the writer and readers is supposed to be relevant; therefore the author deliberately influences the recipient through the purposeful selection of language units for titles. For example, in the following title the words from a popular song by The Platters "Twilight Time" are used in order to draw attention to the text: Heavenly shades of night are falling. In the story Five to One, One in Five the title words from the song of Jim Morrison and the Doors band has become a sinister element in the plot. This phrase performs a prognostic pragmatic function implying the events of the fiction work: Five to one, baby, one in Five, No one here gets out alive now. So, the examples given above demonstrate the fact that the reader with specific background knowledge can build a certain logical chain about the plot of the work and foresee how exactly events will unfold.

Another peculiar feature of allusive paratext is the use of wellknown proper names in the heading. They bring to life specific potentialities, which enhance the expressiveness of the titles of the literary works, e.g. the headline Cain Rose Up appeals to the Bible, the title Batman and Robin Have An Altercation refers to the famous book of comics and superhero movie series, The Gingerbread Girl hints at the scary fairy tale of brothers Grimm about Gretel and Hansel, the New Tales of Cthulhu Mythos collection almost duplicates the title of a famous work about Cthulhu of a horror classic writer H. P. Lovecraft The Call of Cthulhu (1928). The Reaper's Image is an allusion to the Grim Reaper - "Sorrowful Reaper", as Death is often portrayed in European culture as a skeleton with a scythe, dressed in a black sweatshirt with a hood. In the novel Rita Hayworth and Shawshank Redemption the writer uses the name of a famous Hollywood actress of the 1940s, a poster with the image of which helped the protagonist to escape from prison.

Among allusive paratextual elements of S. King's works we have also registered headings denoting time and space. In addition to the cyclic coordinates (Four Past Midnight, Strawberry Spring, The night of the Tiger, The Ten O'Clock People, Graduation Afternoon), the time of action may be indicated by a date which is correlated with a well-known historical event, e.g. 11/22/63 (November 22,63 is the date of the assassination of the USA President John Kennedy). Titles which contain toponyms, real or belonging to the fictional worlds, also create associations important for the plot understanding. In this case the headers have a dual function: attributive and circumstantial, clearly and accurately naming the venue. For example, the title Hearts in Atlantis contains the allusion to the name of a mythological country and hints at the mystery of the events of the work. According to the plot, the main character Riley compares the era of his youth to Atlantis, which disappeared into the depths of the sea and will no longer return. The toponym in the heading Battle of Jericho Hill is strongly associated with the Biblical story of the Israeli leader Joshua who ended his people's 40-year wander through the desert by invading Jericho, defeating it when a blow from the priests' ceremonial horns tumbled the great walls. As for the title Lunch at the Gotham Café we should mention, that Gotham is not only a well-known nickname for New York and a name for Batman's fictional city, but it is also a village in Nottinghamshire, England, which is associated in folklore with insanity [11]. This fact explains the author's choice of the café with such a name as the background for the rampage behavior of the protagonist.

Names of mythological, historical, literary characters, denoting such concepts, which stand out for their definiteness, durability and popularity, are stable lexical units with significant suggestive and associative capacity: American Vampire, Cycle of the Werewolf, The Boogeyman, The Demons, Johnathan and the Witches, The Eyes of the Dragon, The Leprechaun, The Tommyknockers ("Tommyknocker" is the American variant and a Tocker is a Welsh name of the Irish Leprechaun [12], but S. King's creatures have nothing in common with this folklore character). As we can see, these titles contain tokens that denote well-known Western mythological creatures. It makes the headlines especially attractive and interesting for a reader, as they create the fairy tale atmosphere. The title $I \mathrm{Am}$ the Doorway is actually the statement contained in John's Gospel 10:7 and is the third of the seven statements "I am" of Jesus. These proclamations are supposed to indicate his unique, divine identity and purpose. In this statement Jesus clearly points to the exceptional nature of salvation. In S. King's work this phrase has a more direct meaning, because the main character considers himself "the door" to alien invasions and horrific murders. Titles Suffer Little Children (Matthew 19:14) and If Thy Right Hand Offend Thee, Cut It Off (Matthew 5:30) also belong to the direct Biblical allusions.

Some titles of S. King's works represent literary allusions. For example, the heading of the storybook He Is Legend is inkling to Richard Matheson's book I am a Legend (1954) to which this anthology was devoted. The next paratextual element - 
Here Be Tygers - is the tribute to the novel written by Ray Bradbury (1951). It is thought that this phrase comes from the ancient times of the first geographical findings, when maps of uncharted areas often contained Latin phrases like "Hic sunt leones" ("here may be lions"), so the word "tygers" is written in English in archaic form [14]. The allusive name of the story The Pit and the Pendulum also duplicates the title of another literary text. This is a direct allusion to the work of the father of horror literature Edgar Poe with the same title (1842). In the story Sleeping Beauties women go to sleep in a sticky white cocoon, so, we see a hint on the famous Ch. Perrault's tale Sleeping Beauty (La Belle au bois dormant, 1697). According to the plot, when women fall asleep, they find themselves in a different, better place, where harmony reigns and conflicts are extremely rare, but if the shell covering their heads gets damaged or broken and wakes them up, they become wild and incredibly violent.

In the course of our analysis of paratextual elements in S. King's literary works we have also distinguished titles with idiomatic components. For example, the heading Monster in the Closet refers to the English idiom "skeleton in the closet", used to describe secret shameful facts about someone, but in this literary work a true "skeleton" (monster) appears in a real closet. The idiomatic title One for the Road reflects the expression that appears in the beginning of the story in its main meaning - characters are having one last drink before going home. Nevertheless, in the course of the story this phrase takes on a more specific meaning - "one, alone on the road, on the way", as the main characters meet vampires on a deserted road and are forced to fight them all alone. The following headings also represent idiomatic allusive paratext: Deep Water (it is a part of the idiom "deep waters run deep"), Under Weather, Dreaded X, Finders Keepers, Bag of Bones. It is remarkable that the former phrase is used in the denotative meaning of its components as the story isn't connected with anybody skinny or extremely thin, but with real bones, remnants of victims in a bag.

As we've already mentioned, the task of the title of a literary work is to attract the reader's attention, to hint at the main object of the work and the important role here is played by the background knowledge of the reader. To this end, modern writers often use specific terminological or borrowed vocabulary in the headlines, demonstrating their intellectual level. Naming his essay The Nightmare in the Sky: Gargoyles and Grotesques, S. King may suppose, that a reader knows, that a gargoyle is a stone-cut extended sculptural figure in the form of a head of fantastic beasts, monsters, men etc., in the Middle Ages it was a characteristic element of Romanesque and Gothic architecture. The word "grotesque" usually means "weird, fantastic, eccentric, or ugly", and is often used to describe ancient distorted forms, such as Halloween masks or gargoyles on cathedrals. Thus, the author assumes that the reader has some certain knowledge on the terminology related to the world of art and ancient architecture. The title Turning the Thumbscrews on the Reader also presumes that the audience is acquainted with medieval methods of torture. The thumbscrew is an instrument of torture for crushing the thumbs used during the times of Spanish Inquisition. As for usage of foreignisms, we should point out the following titles: New Terror Omnibus and Danse Macambre. "Omnibus" (French) is not just a collection of literary works, but also this word in Latin means "all", so we have a play on words "New horrors for all". The heading in the second example (French for "The Dance of Death") verbalizes the terminological concept of the Dancing Death in the History of the Art - a widespread story in Western European culture, originally in mottoes and literature, later in frescoes, paintings and series of engravings from the 14th to the 20th centuries, as well as in music and theater. Frequency of the usage of such types of titles can obviously be explained by their informative brevity, limited content capacity, and, therefore, the ability to attract readers' attention, their curiosity. The polysemantic titles, that make associations unambiguous in the reader's mind and predict the content of the story, are also predictably controversial. These are headlines like: Rose Madder. "Madder" stands for "the madder staining plant". The English name of the plant is in tune with the word "mad" - "crazy".

The name-phrase in In the Tall Grass comes from the sports jargon. This collocation means scoring the ball outside the golf field, which causes difficulties for the player. The expression is used figuratively, because the protagonists do not play golf but are in a difficult position. The heading One Drop of Blood represents an allusion to the "One drop rule", which is an unofficial household and cultural setting that existed until the mid-20th century, especially in the US, and consisted in the strict observance of the theory of "purity of race", according to which a person with the smallest percentage of another race blood should be considered "black" [15]. The heading Flight or Fright represents a paraphrase, a hint on the medical term "Fight or Flight", which stands for "physiological changes in the body (such as increased heart rate or bronchial enlargement) in response to stress" [5]. The title Sun Dog is also pragmatically attractive as it has an ambiguous allusive meaning. The reader may suppose that the writer means "phantom suns" - patches of light that sometimes appear beside the sun and are called "sundogs" (Gr. parhelion). These phenomena are called so because they follow the sun like a dog follows its master [16]. However, the story tells about a monster dog which appears every time as the Polaroid camera named Sun 660 is used.

Conclusions. Thus, as we can see from the examples given above, the technique of allusion in the paratext is very productive; it is used for compression and promotes the function of influence. With the help of idioms, pun and other expressive means the author created original attractive headlines that are well-remembered and catch the attention of the reader. Headings in S. King's works are not just phrases prefaced to the entire text, they are the artistic means of creating meaningful completeness. Directing the reader with paratext to a particular set of events, the writer creates an internal subtext that prepares for the perception of the book. The analysis revealed that allusive, artistically conditioned and significant paratextual elements hint to the idea of the story, the turning points of the plot, to the main characters and prepare the reader for the proper understanding of the message. The prospects for future investigation are seen in the possibility of analyzing functions of allusive epigraphs in S. King's stories.

\section{References:}

1. Ashley K. The Miroir des bonnes femmes: not for women only? Medieval conduct. Minneapolis : University of Minnesota Press, 2001. P. 86-105.

2. Brown C. J. Paratextual Performances in the Early Parisian Book Trade: Antoine Verard's Edition of Boccaccio's Nobles etcleres dames (1493). Cultural Performances in Medieval France: Essays in Honor of Nancy Freeman Regalado. Cambridge : D. S. Brewer, 2007. P. 255-264.

3. Burke P. Cultures of translation in Early Modern Europe. Cultural Translation in Early Modern Europe / [eds. Burke P., Pochia Hsia R.]. Cambridge : Cambridge University Press, 2007. P. 7-38. 
4. Complete library of Stephen King works. URL: https:// www.stephenking.com/the library.html.

5. Flight-or-Fright. URL: https://www.merriam-webster.com/dictionary/ fight-or-flight.

6. Genette G., Maclean M. Introduction to the Paratext. New Literary History. 1991. № 22 (2). P. 261-272. URL: https://www.jstor.org/ stable/469037.

7. Genette G. Palimpsestes: La litterature au second degré. Paris : Éditions du Seuil, 1982. 512 p.

8. Genette G. Paratexts: Thresholds of Interpretation. Cambridge : Cambridge University Press, 1997. 427 p.

9. Kubryakova E.S., Shakhnarovich A.M., Sakharnyj L.V. Chelovecheskyj faktor $\mathrm{v}$ jazyke. Jazyk y porozhdenye rechy [Human factor in language. Language and the birth of speech]. Moscow : Nauka, 1991. 240 p.

10. Kuzmina N. A. Intertekst i yego rol' v protsessakh evolyutsii poeticheskogo yazyka [Intertext and its role in processes of evolution of poetic language]. Moscow : Komkniga, 2007. 272 p.

11. Lowbridge C. The real Gotham: The village behind the Batman stories. URL: https://www.bbc.com/news/uk-englandnottinghamshire-24760791.

12. McIntyre E. The Faeries of the Cornish Tin Mines - Cousin Jack and the TommyKnockers. URL: https://www.transceltic.com/cornish/ faeries-of-cornish-tin-mines-cousin-jack-and-tommyknockers.

13. Monaghan P. The Encyclopedia of Celtic Mythology and Folklore. New York : Facts on File, 2004. 512 p.

14. Shapiro M. Language Lore. URL: https://languagelore.net/2013/01/30/ hic-sunt-leones.

15. Wright L. One Drop of Blood. The New Yorker. 17 July 1994. URL: https:/www.newyorker.com/magazine/1994/07/25/one-drop-ofblood.

16. Zimmermann K. Ann Sundogs: Spots of Color beside the Sun. Planet Earth. 18 January 2013. URL: https://www.livescience.com/26402sundogs.html.

Борисова Т. С. Алюзивний заголовок у творах С. Кінга

Анотація. У статті розглядається стилістичний потенціал алюзивних паратекстуальних елементів у художніх творах американського письменника Стівена Кінга. Опи- совий та порівняльний методи, а також структурно-семантичний та контекстуальний аналіз дозволили виявити основні засоби концептуалізації паратекстуальних елементів та визначити їх функції на матеріалі з 620 літературних текстів С. Кінга. Оскільки більшість літературних текстів мають певну структуру та специфічний комунікативно-прагматичний зміст, у нашій роботі ми досліджуємо не тільки сам художній текст, а й текстову периферію, яка має специфічне значення та значно впливає на читача у подальшому розумінні сюжету твору. У нашій розвідці ми зробили спробу визначити комунікативний потенціал паратекстуальних елементів та шляхи їх мовної реалізації, а також встановити їх функціональне значення на матеріалі оповідань, романів та есе С. Кінга. Було визначено, що алюзивна назва $є$ базовою паратекстуальною одиницею, яка несе фактичну, концептуальну та підтекстову інформацію в аналізованих літературних творах, а також вносить у художній простір значний шар культурних даних. Для того, щоб налаштувати читача на певний перебіг подій у тексті, С. Кінг часто використовує інтертекстуальні заголовки, пов'язуючи таким чином нову історію з так званими культурними реаліями. Цей зв'язок встановлюється через подання прямих та непрямих цитат та залучення відомих літературних персонажів чи інших відомих постатей алюзій, які є дуже ефективними у сильних позиціях тексту. Алюзивний заголовок, який зазвичай близько пов'язаний з підтекстом всього оповідання або роману, сприяє цілісному розумінню літературного твору, оскільки назви несуть точну семантичну проекцію змісту відповідного тексту та виступають елементом діалогу «автор - читач». У процесі нашого дослідження паратекст, що містить заголовок, епіграфи, короткі передмови та присвячення та відіграє важливу роль у художньому та семантичному осмисленні художньої літератури, був визнаний незмінним елементом творів С. Кінга. Паратекст тісно пов'язаний з подальшим текстом і слугує чітко продуманою проекцією його змісту та путівником для читача.

Ключові слова: паратекст, паратекстуальний елемент, назва, алюзія, проекція змісту. 